Buca Eğitim Fakültesi Dergisi, 2021, say1 52, s. 764-779

Araştırma Makalesi
The Journal of Buca Faculty of

Education, 2021, issue 52, p. 764-779

Research Article

\title{
Uluslararası Sertifikalı Londra Müzik Koleji (London College of Music-LCM) Müzik Eğitim Programının Özengen Piyano Eğitimindeki Yeri*
}

\author{
The Position of the Internationally Certified London \\ College of Music (LCM) Education Program in the \\ Field of Amateur Piano Education
}

\author{
Onur AKINÖNDER ${ }^{1}$, Esin UÇAL CANAKAY ${ }^{2}$
}

\begin{abstract}
${ }^{1}$ Ögretmen, Eğitim Bilimleri Enstitüsü, Dokuz Eylül Üniversitesi, Türkiye, onurakinonder@gmail.com, (https://orcid.org/0000-0001-6701-3509)

${ }^{2}$ Sorumlu Yazar, Dr. Öğr. Üyesi, Güzel Sanatlar Eğitimi Bölümü Müzik Eğitimi Anabilim Dall, Buca Eğitim Fakültesi, Dokuz Eylül Üniversitesi, Türkiye, esin.canakay@deu.edu.tr, (https://orcid.org/0000-0003-2476-8287)
\end{abstract}

Geliş Tarihi: 01.12.2021

Kabul Tarihi: 21.12.2021

Öz

Bu çalışmada amaç uluslararası sertifikalı müzik eğitimi programları arasında yer alan Londra Müzik Koleji (London College of Music-LCM) programının özengen müzik eğitimi veren piyano eğitimcilerinin görüşleri doğrultusunda incelenmesidir. Bu araştırmada nitel araştırma veri toplama yöntemlerinden görüşme tekniği kullanılmıştır. Araştırmanın çalışma gurubunu İzmir ili içerisinde LCM uluslararası sertifika programına öğrencilerini dâhil ederek LCM uluslararası sertifikalı müzik eğitimi programı piyano kitaplarını kullanan 20 piyano eğitimcisi oluşturmaktadır. Piyano eğitimcileriyle yapılan görüşmeler sonucu elde edilen verilere içerik analizi yapılmıştır. Buradan elde edilen bulgulara göre; görüşmeye katılan eğitimcilerin LCM uluslararası sertifika programı ve sertifikaların geçerlilikleri hakkında yeterli bilgiye sahip olmadığı görülmektedir. LCM sertifikalarının uluslararası geçerliliği olması nedeniyle bu programın tercih edildiği fakat sınav ücretlerinin yüksek olması nedeniyle başarılı olabilecek her öğrencinin bu programlara yönlendirilemediği de ifade edilmektedir. Ancak, LCM piyano kitaplarının yalnızca sertifika programlarına dâhil olan öğrenciler için değil, programlara dâhil olmayan öğrencilerin de piyano eğitimi için kullanıldığı ifade edilmektedir. Ayrıca LCM piyano kitaplarının içerisinde yer alan açıklamaların Türkçe olmaması nedeniyle kitapların anlaşılması açısından sıkıntı yaşandığı ve programların özengen piyano eğitimi alan bireylerde sınav kaygısına neden olarak çalgıdan uzaklaştırdığı da ifade edilmektedir.

Anahtar Kelimeler: Özengen (amatör) müzik eğitimi, piyano eğitimi, uluslararası sertifikalı müzik eğitimi programi.

\section{ABSTRACT}

The aim of this research is to examine London College of Music (LCM) program, one of the internationally certified music education programs, in accordance with the opinions of the piano educators who are

\footnotetext{
* Bu çalışma, Onur Akınönder'in Dr.Öğr.Üy. Esin Uçal Canakay danışmanlığında yürüttüğü ve 2019 yılında Dokuz Eylül Üniversitesi Eğitim Bilimleri Enstitüsü tarafından onaylanmış olan yüksek lisans tezinin bir bölümünden hazırlanmıştır.
} 
proficient in music education. In this study, the interview technique, which is one of the qualitative research data collection methods, was used. The study group of the research consists of 20 piano educators who use the piano books of the LCM internationally certified music education program by including their students in the LCM international certificate program in Izmir. Content analysis was performed on data obtained as a result of interviews with the piano educators. According to the findings obtained here; it is observed that the educators who participated in the interview did not have sufficient information about the validity of the LCM international certificate program and certificates. It is also stated that this program is preferred due to the international validity of LCM certificates, but not every student who can be successful cannot be directed to these programs because of the high examination fees. However, it is stated that LCM piano books are used not only for the students who are included in the certificate programs but also they are used for the students who are not included in the programs. In addition, it is stated that because the explanations in the LCM piano books are not in Turkish, there is a difficulty in understanding the books, and the programs are taken away from the instrument as a reason for exam anxiety in the amateurs who are proficient in music education.

Keywords: Amateur music education, piano education, international music education certification program.

\section{GIRIŞ}

Çağdaş eğitimin temel öğelerinden biri olan sanat eğitimi, bireyin okulda ve okul dışında geçen zamanını verimli kullanması, bireyin gelişimi ve yaratıcı yönü gelişmiş bireyler kazandırılması açısından büyük önem taşımaktadır. $\mathrm{Bu}$ nedenle sanat eğitiminin yaygınlaştırılması önem arz etmektedir. Sanat eğitiminin en önemli dallarından biri olan müzik eğitimi, bireyin kendini ifade etmesini sağlayan, kişinin estetik bakış açısını ve özgüvenini geliştiren, dikkat ve kavrama becerisini arttıran ve yaratıcı yönlerini keşfetmesini sağlayan bir alandır. "Sanat eğitimi içinde yer alan müzik eğitimi; insanın eğitilmesi, duyguların olgunlaşması, sanat ve güzelliğin felsefesi olan estetik bilincin oluşması, insan ve toplum değerlerinin kazandırılması açısından sanat eğitimi içerisinde en geçerli olanıdır" (Cemalcılar, 1985, s. 74).

Müzik eğitimi amaçları bakımından genel müzik eğitimi, mesleki müzik eğitimi ve özengen (amatör) müzik eğitimi olmak üzere üç kısımda ele alınmaktadır. Genel müzik eğitimi, Milli Eğitim Bakanlığı'na bağlı ilkokul, ortaokul, lise ve diğer özel okullarda verilmekte olan, haftalık belli bir zaman dilimini kapsayan, normal eğitim sürecinde belirlenmiş bir program dâhilinde yürütülen ve bu okullardaki programı alan bütün öğrencilerin aldığı bir eğitim olarak tanımlanabilir (Türkmen, 2017, s. 11). Genel müzik eğitimi, sağl1klı ve dengeli bir yaşam için ayrım gözetmeksizin herkese yönelik olarak asgari ve ortak olan genel müzik kültürünü kazandırmayı amaçlayan müzik eğitimi türüdür (Tarman, 2006, s. 9).

Mesleki müzik eğitimi, en genel anlamıyla müzik sanatını meslek olarak benimseyen bireyler için düzenlenen ve bu bireylere mesleğin gereği olan müzikal bilgi ve birikimi kazandırmayı hedefleyen etkinlikler bütünüdür. Müziği bilinçli olarak algılayan, yaratan, yorumlayan, kuramını çözümleyen, araştırıp inceleyen ve öğreten sanat, bilim, eğitim insanları yetiştirmeyi hedefler.

Özengen müzik eğitimi ise şu şekilde tanımlanmaktadır (Uçan, 2005, s. 32):

Özengen müzik eğitiminde, daha çok, müziği izleyip dinleyerek tüketen ya da kullanan kitleler yerine, müziği herhangi bir parasal ya da maddi karşıllk beklemeksizin, yalnızca zevk ve doyum sağlamak için yaparak yaşayan ve bunu adeta kendisi için bir yaşam tarzına dönüştüren müzikseverler ve amatör müzikçiler yetiştirmeye dönük bir strateji uygulanır. Müziksel ögrrenmenin son derece kalıcı izli olduğu bu tür uygulamalarda, özengen (özenmen) bireyin ilgisi, isteği, yatkınlı̆ğ ve yeteneği doğrultusunda ve ölçüsünde gelişerek etkin katılımda bulunması ve doyum sağlaması esastır. 
Müziğe ilgi ve sevgi duyanlara yönelik olan özengen müzik eğitimi, etkin bir müziksel katılımla doyum sağlayarak bunu geliştirmek için gerekli müziksel davranışları geliştirmeyi amaçlamaktadır. Bireyin yetenekli değil istekli olması ön plandadır ve genellikle müzik dershaneleri, kurslar, özel dersler yoluyla müzik eğitimcisi ya da çalgı öğretmeni tarafindan yürütülmektedir. Özengen müzik eğitimi ayrıca, mesleki müzik eğitimine hazırlayıcı ya da onun alt basamağ 1 olarak da işlev görmektedir (Tarman, 2006, s. 10).

Ülkemizde özengen müzik eğitimi faaliyetleri belediyelere bağl1 kültür müdürlükleri, özel müzik kursları ve özel çalışan müzik eğitimcileri tarafından yürütülmektedir. Bu kurumların ve özel çalışan müzik eğitimcilerinin amacı farklı yaş gruplarından bireylere isteklerine ve ilgi alanlarına göre sanatın çeşitli dallarında eğitim vermektir.

Günümüzde bireyde sağladığı kazanımlar nedeniyle müzik eğitimine ve onun bir boyutu olan çalgı eğitimine ilgi giderek artmaktadır. Bireylerin ilgi alanları ve istekleri göz önünde bulundurularak çalg1 eğitimi genellikle özengen müzik eğitimi kurumlarında ya da özel dersler ile verilmektedir. Tuşlu bir çalgı olması ve başlangıç aşamasında üflemeli, telli ve yaylı çalgılara göre daha kısa sürede sonuç alınabilmesi nedeniyle de piyano, öğretmen ve öğrencilerin ilk tercih ettiği çalgılar arasında yer almaktadır.

Çok sesli bir çalgı olması; deşifre becerisi, kulak gelişimi, armoni ve form bilgisi alanındaki gelişim; transpozisyon ve müzikal gelişime katkısı nedeniyle müzik eğitimi alan her birey piyano eğitimine gereksinim duymaktadır. Bu nedenle konservatuvarlar ve çeşitli müzik okullarında "yardımcı piyano" dersi okutularak, bu dersler ile branşı ne olursa olsun müzik eğitimi alan öğrencilerin yukarıdaki konular hakkında gelişimlerini sağlamak ve mesleklerinde onlara yardımcı olabilecek bilgiler vermek amaçlanmaktadır. Pedagoglar tarafindan ilkokul dönemi olarak nitelendirilen 6-11 yaş grubunun, çocuğun zihinsel yeteneklerinin hızla geliştiği bir dönem olması nedeniyle piyanoya başlamak için en uygun zaman dilimi olduğu ifade edilmektedir (Saraç ve Saraç, 2018, s. 19, 21).

Rauscher, Shaw ve Katherine (1995, s. 44-47) tarafindan 78 anaokulu öğrencisi üzerinde yapılan araştırmada, sekiz ay haftada iki kez 15 'er dakika piyano dersi alan çocukların almayanlara oranla IQ'larında \%46'lık bir gelişimin söz konusu olduğu ortaya koyulmuştur. Bu sonuca dayanarak okulöncesi çocukların fen ve matematik alanında üstün özellikler göstermeleri açısından gerekli olan zihinsel yapının geliştirilmesinde çocuklara piyano dersi verilmesinin etkili bir yol olduğunu belirtmektedirler.

Milli Eğitim Bakanlığı'na bağlı olarak hizmet veren özengen sanat eğitimi kurumlarında öğrencilerin çalgı dersleri müfredatlar çerçevesinde belirlenmekte, yapılan seviye tespit sınavları sonucunda aldıkları eğitime ilişkin belge verilmektedir. Milli Eğitim Bakanlığı onaylı bu belgeler dışında belirli standartlar belirlenerek uluslararası seviyelendirilmiş sertifikalı müzik eğitimi programları da ülkemizde giderek yaygınlaşmaktadır. Bu programlara dâhil olan öğrencilere uygulanan seviye sınavları sonucunda verilen sertifikaların uluslararası geçerliliği olması nedeniyle bu programlar öğrenciler ve velileri tarafından tercih sebebi olmaktadır.

Ülkemizde Milli Eğitim Bakanlığı'na bağlı olarak hizmet veren özengen sanat eğitimi kurumları bünyesinde sürdürülen uluslararası sertifikalı müzik eğitimi programlarından biri Londra Müzik Koleji (London College of Music-LCM) tarafindan yürütülen programdır.

LCM uluslararası seviyelendirilmiş sertifikalı müzik eğitimi programı adı altında birçok ülkede periyodik olarak seviye sınavları düzenlenmektedir. Genel, mesleki ve özengen müzik eğitimi alan her birey bu sınavlara katılma hakkına sahiptir. Düzenlenen sinavlar sonucunda başarılı olan öğrencilere aldıkları sınav notlarına göre girdikleri seviyeye ait uluslararası uygunluk ve değerlendirme kurulları tarafından incelenerek gerekli standartlara sahip olan, tüm dünyada geçerli belgeler verilmektedir.

LCM bünyesinde piyano, müzik tiyatrosu, şan, müzik teorisi, klavye, org, akordeon, gitar, ukulele, vurmalı çalgılar, yaylı çalgılar, arp, tahta nefesli çalgılar, bakır üflemeli çalgılar, 
geleneksel müzik, caz, kilise müziği, şeflik, kompozisyon, okul müziği performans1, profesyonel başarı, radyo ve podcasting, orkestra müziği (ensemble), drama ve iletişim alanlarında uluslararası sertifika programları bulunmaktadır. Bu programlardaki her seviye için özel olarak hazırlanmış kitaplar kullanılmaktadır. Kitapları olmayan alanlar için repertuvar listesi ve sınav içerikleri belirlenmektedir (https://www.uwl.ac.uk/academic-schools/music/about-school).

LCM müzik sınavlarını seviye ve diploma sınavları olarak sınıflandırmaktadır. Seviye sınavları öncesinde başlangıç düzeyindeki öğrenciler için ön hazırlık (pre-preparatory), aşama 1 (step 1) ve aşama 2 (step 2) programları uygulanmaktadır. Yeterli seviyeye gelen öğrenciler ise kolaydan zora doğru seviye 1'den (grade 1) seviye 8'e (grade 8) kadar aşamalı bir sinava tabi tutulmaktadır. Her seviye sınavı sonrasında LCM sınav görevlisi tarafından aday hakkındaki görüşlerin yazılı olduğu rapor öğrencilere teslim edilir. Sınav değerlendirme ölçütleri ise şu şekildedir: \% 0-64 Başarısız (Unsuccessful), \% 65-74 Geçer (Pass), \% 75-84 Başarılı (Merit), \% 85-100 Yüksek Şeref (Distinction) (https://lcme.uwl.ac.uk/exams/grades).

London College of Music tarafindan düzenlenen 1, 2 ve 3. seviye sinavlarının nitelikler çerçevesi İngiltere'nin müfredat ve değerlendirme kurulu "Council for the Curriculum, Examination and Assessment" ve belge veren kuruluşlara kriterler belirleyen kurumu olan "Qualifications Wales" tarafından düzenlenmiştir. 6, 7 ve 8. seviyelere İngiltere'deki üniversiteler için yıllık puanlarını belirleyen ve öğrencilerin üniversitelere yerleşmesini sağlayan kurum olan UCAS (Universities and Colleges Admissions Service) tarafından puan verilmektedir. LCM'nin dereceli sınavları Avrupa Yeterlilikler Çerçevesi'ne (European Qualifications Framework) dâhil edilmiştir (https://lcme.uwl.ac.uk/exams/grades).

LCM uluslararası seviyelendirilmiş sertifikalı müzik eğitimi programlarından piyano alanına ait her seviye sınavı için farklı kazanım ve içeriğe sahip kitap bulunmaktadır. Kitapların içeriklerinde egzersiz, etüt ve performans eserlerinin teknik açıdan kolaydan zora doğru sıralandığ 1 , tartışma, deşifre ve işitsel testler bölümlerinde ise basitten karmaşı̆ga doğru bir yol izlendiği görülmektedir. Adayların, sertifika sınavlarında başarılı olabilmeleri için bu kitaplar içerisinde belirlenmiş teknik, teorik ve müzikal kazanımlar açısından yeterliliğe sahip olmaları gerekmektedir.

Sertifika programlarına dâhil olan öğrencilerin belirli aralıklarla sınavlara tabi tutulmaları, öğrencileri sınavlara yönelik daha ciddi çalışma yapmaya teşvik etmektedir. Ancak öğrencilerde çalışma disiplini oluşturmasının yanı sıra kendi isteği dışında bu programlara dâhil edilen öğrencilerin hobi amaçlı aldığı eğitimin temel hedefleri ile çelişerek öğrenciyi olumsuz yönde etkileyebilmektedir. Bu doğrultuda bu araştırma, özengen müzik eğitimi bağlamında piyano özel dersi veren müzik eğitimcilerinin LCM uluslararası seviyelendirilmiş sertifikalı müzik eğitimi programı ve programın piyano alanına ait kitaplarına ilişkin görüşlerinin betimlenmesi amacıyla yapılmıştır.

Çalışma alanı ile ilgili literatür incelendiğinde özengen müzik eğitimi ile ilgili bazı çalışmalar dikkat çekmiştir. Türkmen (2010), çalışmasında çocuğun bireysel, toplumsal ve kültürel gelişiminde özengen müzik eğitimin önemini belirlemek ve özengen müzik eğitiminin çocuk üzerindeki etkisini ortaya koyarak eğitimin daha etkin yürütülebilmesi amaciyla var olan problemlere çözüm önerileri getirmeyi amaçlamıştır. Araştırmanın sonucunda, 7-12 yaş arası çocukların bireysel, toplumsal ve kültürel gelişimlerinde özengen müzik eğitiminin önemli bir yere sahip olduğu ve gerekliliği vurgulanmıştır. Ayrıca müzik eğitimi konusunda Türk aile yapısı ve toplumunu bilinçlendirmek açısından özengen müzik eğitiminin önemi ortaya koyulmuştur.

Karan (2011), Türkiye'de özengen müzik eğitimi kurumlarından çalg1 eğitimi alan öğrencileri mesleki yönelimlerinin incelenmesini amaçlayan bir araştırma gerçekleştirmiştir. Araştırma sonucunda, özengen müzik eğitimi kurumlarından çalgı eğitimi alan öğrencilerin büyük bir bölümü kendi istekleri ve ailelerin teşviki ile çalg1 eğitimine başladıkları, isteyerek devam ettikleri ve devamsızlık yapmadıkları, çalgı eğitimi alan öğrencilerin farklı müzik 
türlerine ilişkin ilgilerinin arttığı, öğrencilerin müziği meslek olarak seçme düşüncesinde oldukları ve ailelerin çocuklarının müziği meslek olarak tercih etmelerini istedikleri görülmüştür.

Basut (2013), "Türkiye'de Uygulanan Kraliyet Müzik Okulu Sınavlarının Etki ve Sonuçlarına Yönelik Bir Değerlendirme" konulu yüksek lisans tezinde 1990 y1lından beri Türkiye'de faaliyet gösteren Kraliyet Müzik Okulları Birleşik Kurulu'nun işleyişini ve söz konusu seviye sınavlarının müzik eğitimine katkılarını piyano eğitimcisi, öğrencisi ve öğrenciveli deneyimleri açısından incelemiştir. Araştırma sonuçlarına göre piyano öğretmenlerinin çoğunluğu İngiliz Kraliyet Müzik Okulları Birleşik Kurulu (KMOKB) işbirliğinde verilen seviye diplomalarının uluslararası öneminin farkında olduklarını belirtmişlerdir. Ayrıca araştırma sonuçlarına göre KMOBK seviye sınavlarına giren öğrencilerin girmeyenlere göre aralık, akor, gam ve arpej bilgisi konusunda daha iyi oldukları, dikte yazma ve solfej okuma solfej okumada daha başarılı oldukları vurgulanmıştır.

Oktay (2017), yüksek lisans tezinde özengen müzik eğitiminde yaygın olarak kullanılan uluslararası geçerliliğe sahip müzik sertifika programlarının ülkemizdeki işleyişini ve programlara dâhil olan öğrencilerin katılım amaçlarını incelemiştir. Yapılan araştırmada sertifika programlarına katılan öğrenciler ve velilerin büyük çoğunluğu tarafindan bu programların özengen müzik eğitimi programlarından farklı görülmediği, sertifikaların olası yurt dışı eğitimi için burs imkânı sağlaması amacıyla istendiği, programlara katılan öğrencilerin katılmayanlara oranla piyano eğitimini daha çok ciddiye aldığ 1 ve çalışma disiplinlerine olumlu etki ettiği, kurs yöneticileri tarafindan kurs merkezi seçiminde bu programların etkili olduğunun düşünüldüğü sonucuna varılmıştır.

Hellman ve Mcdowell (2011), sertifikalı müzik eğitimi programlarına kaydolma, devam etme ve tamamlama faktörlerinin incelenmesi amacıyla bir araştırma yapmışlardır. Araştırma nitel araştırma yöntemlerinden görüşme ile yapılmıştır. Araştırmaya katılan 43 eğitimci adayının bu programları tercih etme nedenlerinin sağladığı kişisel destek, ögretmenliklerine olumlu etki etmesi, yüksek seviyeli şeyler öğrenmeleri ve iş imkânları sunması olduğu görülmüştür.

Dumlavwalla (2011), araştırmasında Royal College of Music sınav görevlilerinin bu sınavları yürütebilmek açısından yeterliliklerini incelemeyi amaçlamıştır. Araştırmaya katılan 10 sınav görevlisi ile görüşme yapılmıştır. Araştırma sonucunda sınav görevlilerinin staj programları sirasında yapılan sinıf seminerleri ile deneyimlerini birbirlerine aktarma firsat buldukları ve bu programların öğrencileri gözlemleyerek danışmanlarıyla bilgi alışverişinde bulunmalarını sağladığı görülmektedir.

İncelenen çalışmalar ışı̆̆ında, Türkiye'de faaliyet gösteren LCM uluslararası sertifikalı müzik eğitimi programı ve programın piyano alanına ait kitaplarının piyanoda özel ders veren müzik eğitimcilerinin görüşleri doğrultusunda değerlendirilmesinin özengen piyano eğitimine sağlayacağı katkı açısından faydalı olacağı düşünülmektedir.

\section{YÖNTEM}

$\mathrm{Bu}$ araştırma, nitel araştırma yöntemlerine göre oluşturulmuştur. $\mathrm{Bu}$ doğrultuda nitel araştırma yöntemi tekniklerinden görüşme tekniği kullanılarak uluslararası sertifikalı müzik eğitimi programlarının özengen müzik eğitimi kurumlarında yürütülmekte olan piyano derslerindeki yerine ilişkin durum var olduğu şekliyle betimlenmiştir. Görüşme tekniği bireylerin deneyimlerine, tutumlarına, görüşlerine, şikayetlerine, duygularına ve inançlarına ilişkin bilgi elde etmede etkili bir yöntem olmakla birlikte sosyal bilimler alanında kullanılan en yaygın veri toplama yöntemidir (Briggs, 1986; aktaran Yıldırım ve Şimşek, 2016, s. 129). 


\section{1. Çalıșma Grubu}

Araştırma grubunu İzmir'de LCM uluslararası sertifikalı müzik eğitimi programına öğrencilerini dâhil ederek program kitaplarını kullanan, özengen müzik eğitimi veren 20 piyano eğitimcisi oluşturmaktadır. 7'si erkek, 13'ü kadın toplam 20 eğitimciye ilişkin bilgiler tablo 1'de yer almaktadır.

Tablo 1. Görüşmeye Gönüllü Olarak Katılan Piyano Eğitimcilerine İlişkin Bilgiler

\begin{tabular}{|c|c|c|c|c|c|c|c|c|}
\hline 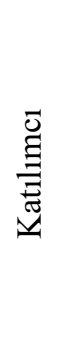 & 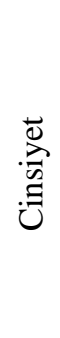 & $\overbrace{}^{\infty}$ & 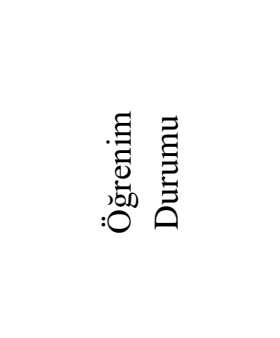 & 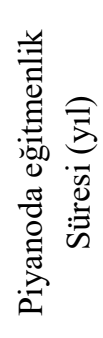 & 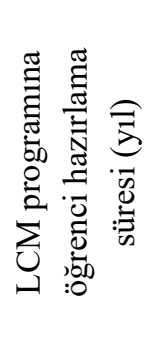 & 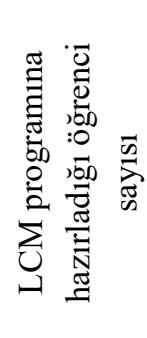 & 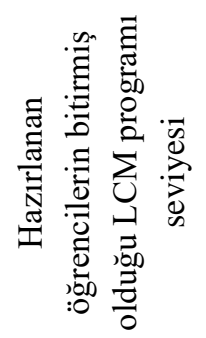 & 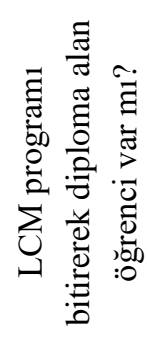 \\
\hline 1 & $\mathrm{~K}$ & 25 & Müzik Öğr. Lisans & 6 & 1 & 3 & 2 & Yok \\
\hline 2 & $\mathrm{~K}$ & 25 & Müzik Öğr. Lisans & 6 & 4 & 9 & 4 & Yok \\
\hline 3 & $\mathrm{~K}$ & 26 & Müzik Öğr. Lisans & 5 & 3 & 8 & 4 & Yok \\
\hline 4 & $\mathrm{E}$ & 31 & Müzik Öğr. Lisans & 7 & 2 & 10 & 4 & Yok \\
\hline 5 & $\mathrm{~K}$ & 24 & Müzik Öğr. Lisans & 6 & 2 & 3 & 2 & Yok \\
\hline 6 & $\mathrm{~K}$ & 36 & $\begin{array}{l}\text { Devlet Kons. } \\
\text { Lisans }\end{array}$ & 15 & 7 & 100 & 8 & Var \\
\hline 7 & $\mathrm{E}$ & 65 & Müzik Öğr. Lisans & 29 & 11 & 80 & 8 & Var \\
\hline 8 & $\mathrm{~K}$ & 26 & Müzik Öğr. Lisans & 5 & 4 & 20 & 8 & Var \\
\hline 9 & $\mathrm{~K}$ & 34 & $\begin{array}{l}\text { Müzik Öğr. } \\
\text { Yüksek Lisans }\end{array}$ & 18 & 6 & 50 & 8 & Var \\
\hline 10 & E & 34 & Müzik Öğr. Lisans & 16 & 5 & 30 & 8 & Var \\
\hline 11 & $\mathrm{~K}$ & 35 & $\begin{array}{l}\text { Devlet Kons. } \\
\text { Lisans }\end{array}$ & 10 & 5 & 10 & 8 & Var \\
\hline 12 & E & 32 & Müzik Öğr. Lisans & 11 & 5 & 4 & 4 & Yok \\
\hline 13 & $\mathrm{E}$ & 40 & Müzik Öğr. Lisans & 19 & 1 & 3 & 2 & Yok \\
\hline 14 & $\mathrm{~K}$ & 34 & Müzik Öğr. Lisans & 14 & 5 & 8 & 4 & Yok \\
\hline 15 & $\mathrm{~K}$ & 32 & Müzikoloji Lisans & 5 & 2 & 4 & 2 & Yok \\
\hline 16 & $\mathrm{~K}$ & 32 & $\begin{array}{l}\text { Müzik Öğr. } \\
\text { Doktora }\end{array}$ & 11 & 5 & 12 & 6 & Yok \\
\hline 17 & E & 29 & Müzik Öğr. Lisans & 7 & 4 & 5 & 3 & Yok \\
\hline 18 & $\mathrm{~K}$ & 25 & Müzik Öğr. Lisans & 5 & 2 & 4 & 2 & Yok \\
\hline 19 & $\mathrm{E}$ & 25 & Müzik Öğr. Lisans & 4 & 2 & 5 & 2 & Yok \\
\hline 20 & $\mathrm{~K}$ & 25 & Müzik Öğr. Lisans & 4 & 2 & 4 & 3 & Yok \\
\hline
\end{tabular}

Tablo 1'de yer alan verilere göre yarı yapılandırılmış görüşmeye katılan eğitimcilerin 15 'i müzik öğretmenliği lisans, 1'i müzik öğretmenliği yüksek lisans, 1'i müzik öğretmenliği doktora, 2'si Devlet konservatuarı lisans, 1'i de Müzikoloji lisans programı mezundur. 11 yıldır LCM programına öğrenci hazırlayan katılımcı, toplamda 80 öğrenci hazırlamış, öğrencilerini 8. Seviyeye kadar hazırlamış ve öğrencileri LCM programı diploması almıştır. LCM programına toplamda 100 öğrenci hazırlamış olan katılımcı ise 7 yıldır LCM programına öğrenci hazırlamakta olup öğrencilerini 8. Seviyeye kadar hazırlamış ve öğrencileri LCM programı diploması almıştır.

\subsection{Veri Toplama Aracı}

Araştırmada LCM uluslararası sertifikalı müzik eğitimi programına kayıtlı olarak LCM piyano kitaplarını kullanan özengen müzik eğitimi veren piyano eğitimcilerinin LCM programı ve piyano kitaplarına ilişkin görüşleri almak için Yarı Yapılandırılmış Görüşme Formu ve 
katılımcıların araştırma kapsamındaki kilisel bilgilerini alabilmek için araştırmacılar tarafından oluşturulan Kişisel Bilgi Formu kullanılmıştır. "Yarı yapılandırılmış görüşmeler, hem sabit seçenekli cevaplamayı hem de ilgili alanda derinlemesine gidebilmeyi birleştirir" (Büyüköztürk, Kılıç Çakmak, Akgün, Karadeniz ve Demirel, 2014, s. 152).

Yarı yapılandırılmış görüşme formu oluşturulurken ilk aşamada 22 soruluk soru havuzu oluşturulmuştur. $\mathrm{Bu}$ soru havuzu 5 müzik eğitimi uzmanının görüşlerine sunulmuştur. Uzamanlardan gelen yanıtlar doğrultusunda gerekli düzenlemeler yapılarak görüşme formunun 8 soru içeren son biçimi oluşturulmuştur. Görüşme Formunda yer alan sorular şu şekildedir:

1. London College of Music (LCM) piyano sertifika programına ilişkin görüşleriniz nelerdir?

2. LCM piyano sertifika sınavları için kullanılan metotların İngilizce olmasına yönelik görüşleriniz nelerdir?

3. LCM piyano metotlarında yer alan müzikal kazanımlar hakkındaki görüşleriniz nelerdir?

4. LCM piyano metotlarında yer alan teknik kazanımlar hakkındaki görüşleriniz nelerdir?

5. LCM piyano metotlarında yer alan teorik kazanımlar hakkındaki görüşleriniz nelerdir?

6. Özengen piyano eğitimi alan bir öğrencinin LCM sertifika sınavı odaklı çalışmalar yapması, çalgısına yönelik yaptığı çalışmaları sizce nasıl etkilemektedir?

7. LCM piyano metotlarından, sertifika programına dâhil etmediğiniz öğrencileriniz için faydalaniyor musunuz?

8. Eklemek istediğiniz başka bir görüşünüz var mı?

Yarı Yapılandırılmış Görüşme Formu'nun uygulamaları için gerekli izinler alınmış ve 20 piyano eğitimcisi ile yapılan her bir görüşme öncesinde Bilgilendirilmiş Onam Formu ile yapılan çalışmanın amacı, nedeni, görüşme süresi ve yeri ile ilgili açıklamalar yapılarak gönüllü olarak çalışmaya katılım sağlandığına dair onay alınmıştır. Kişisel Bilgi Formu ile katılımcıların araştırma kapsamındaki bilgileri alınmıştır. Görüşmeler yaklaşık 20 dakika sürmüştür. Görüşmeler öncesinde eğitimcilerin izniyle yapılan ses kayıtları görüşmeler sonrasında yazıya aktarılmıştır.

\subsection{Verilerin Analizi}

$\mathrm{Bu}$ araştırmada görüşme yapılarak elde edilen verilere içerik analizi yapılmıştır. Birbirine benzeyen verileri belirli kavramlar ve temalar çerçevesinde bir araya getirerek yapılan işlemlerde veriler dört aşamada analiz edilmektedir. Bunlar: verilerin kodlanması, temaların bulunması, kodların ve temaların düzenlenmesi, bulguların tanımlanması ve yorumlanması aşamalarıdır (Yıldırım ve Şimşek, 2016, s. 242, 243).

- Verilerin kodlanması aşamasında yarı yapılandırılmış görüşme ile elde edilen verilerin analizi sonucunda araştırmanın amacına yönelik önemli boyutlar tespit edilerek kodlar oluşturulmuştur.

- Temaların bulunmasi aşamasında, oluşturulmuş olan kodlar incelenerek ortak yönleri bulunmuş ve veriler bu kodlar aracılığıyla kategorize edilmiştir. Kategorilerin ve bu kategorileri oluşturan kodların verileri etkili şekilde temsil edip etmediği konusunda hem uzman görüşü alınmış hem de araştırmacılar arasında fikir birliği oluşturularak bir sonraki aşamaya geçilmiştir.

- Kodların ve temaların düzenlenmesi aşamasında aynı kategori altında yer alan veriler birbirleriyle ilişkilendirilmiş ifade örnekleri ile doğrudan, herhangi bir yorumlama yapılmadan sunulmuştur.

- Bulguların tanımlanması ve yorumlanması aşamasında kategoriler altında yer alan veriler sözcük sıklık hesapları ve basit yüzde hesapları yapılarak analiz edilmiştir. 


\section{BULGULAR}

$\mathrm{Bu}$ bölümde araştırma verilerinin analizleri doğrultusunda elde edilen bulgular yorumlanmıştır.

LCM uluslararası sertifikalı müzik eğitimi programına kayıtlı olarak LCM piyano kitaplarını kullanan özengen müzik eğitimi veren piyano eğitimcilerinin LCM programı ve piyano kitaplarına ilişkin görüşleri, Yarı Yapılandırılmış Görüşme Formu ile toplanmıştır.

Görüşme formundaki ilk soru olan "LCM piyano sertifika programına ilişkin görüşleriniz nelerdir?" sorusuna ilişkin bulgular tablo 2'de yer almaktadır.

Tablo 2. "LCM piyano sertifika programına ilişkin görüşleriniz nelerdir?" Sorusuna Verilen Yanıtların Dağılımı

\begin{tabular}{|c|c|c|c|}
\hline Kategoriler & $\mathrm{f}$ & $\%$ & İfade Örnekleri \\
\hline Program ücretleri & 20 & 37 & $\begin{array}{l}\text { Program ücretleri çok yüksek olduğu için } \\
\text { sertifikaları alabilecek öğrencileri gönül } \\
\text { rahatlığlyla yönlendiremiyoruz. }\end{array}$ \\
\hline Seviyeler arası dengesizlik & 2 & 3.7 & $\begin{array}{l}\text { Kitaplar arasında seviye farkı çok fazla, dengeli } \\
\text { olduğunu düşünmüyorum. }\end{array}$ \\
\hline $\begin{array}{l}\text { Sertifikaların uluslararası } \\
\text { geçerliliği }\end{array}$ & 17 & 31.5 & 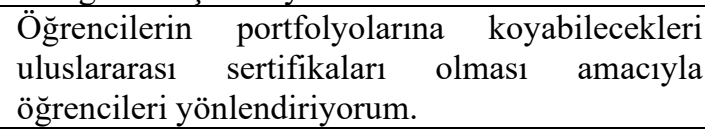 \\
\hline $\begin{array}{l}\text { Programa dahil edilecek öğrenci } \\
\text { seçimi }\end{array}$ & 10 & 18.5 & $\begin{array}{l}\text { Her öğrencime bu programlardan } \\
\text { bahsetmiyorum. }\end{array}$ \\
\hline $\begin{array}{l}\text { Özengen müzik eğitimi } \\
\text { amacından çıkılmasına neden } \\
\text { olma }\end{array}$ & 5 & 9.3 & $\begin{array}{l}\text { Bir amaca ulaşmak için çalışmalar yapmış } \\
\text { oluyoruz. Bu yüzden özengen müzik eğitiminden } \\
\text { çıkıldığını düşünüyorum. }\end{array}$ \\
\hline Toplam & 54 & 100 & \\
\hline
\end{tabular}

Tablo 2'de yer alan "LCM piyano sertifika programına ilişkin görüşleriniz nelerdir?" sorusuna ilişkin eğitimcilerin verdiği yanıtların dağılımına göre program ücretlerine ilişkin görüşlerin en fazla olduğu $(\mathrm{f}=20)$, seviyeler arası dengesizliğe ilişkin görüşlerin ise en az olduğu $(\mathrm{f}=2)$ görülmektedir.

Eğitimcilerin ifadeleri incelendiğinde; LCM piyano sertifika programlarının yüksek sınav ücretleri nedeniyle bu programlara öğrenci yönlendirme konusunda sıkıntı yaşandığ görülmektedir. Bu kategoride dikkati çeken bir başka örnek cümle şöyledir: "Öğrencilerimin ailelerine LCM piyano sertifika programı hakkında bilgi vererek sertifika sınavları için çalışma yapmak istediğimi söylediğimde, bu sene ekonomik anlamda sıkıntıdayız seneye düşünebiliriz diyen velilerim oldu".

Eğitimciler öğrencilerinin uluslararası geçerliliği olan bir belgeye sahip olabilmeleri için sertifika programlarını tercih ettiklerini, sertifikalar nedeniyle öğrenci velilerinden çocuklarını programa dâhil etme talebi geldiğini belirtmektedir. Eğitimcilerin konuyla ilgili ifade ettikleri görüşleri şu örnek cümlelerde görülmektedir: "Öğrencilerim eğer yurt dışında eğitimine devam edecek olursa bu sertifikaların geçerliliği olacağını ve işlerine yarayacağını düşünüyorum”. "Lise çağındaki öğrencilerimin yurtdışı geçerliliği olan sertifikalarla ilgilenmesi nedeniyle bu sınavlara öğrenci hazırlıyorum".

Görüşme yapılan eğitimcilerin her öğrencisine sertifika programları konusunda bilgi vermedikleri ve çalışma disiplini edinmiş başarılı öğrencilerini programlara dâhil ettikleri, programları her öğrenciye duyurmadıkları ve sertifika sınavlarını başarabilecek öğrencileri programlara hazırlamayı tercih ettikleri ( $\mathrm{f}=10)$ görülmektedir. Ayrıca eğitimciler tarafından öğrencilerin sertifika programına dâhil olmasıyla birlikte özengen müzik eğitimi amacından 
çıkıldığ 1 , sınav odaklı planlı çalışma yapılmaya başlandığı $(\mathrm{f}=5)$, LCM sertifika programlarına ait piyano kitaplarının dengeli bir şekilde seviyelendirilmediği $(\mathrm{f}=2)$ ifade edilmektedir.

"LCM piyano sertifika sınavları için kullanılan kitapların İngilizce olmasına yönelik görüşleriniz nelerdir?" sorusuna ilişkin bulgular tablo 3 'te yer almaktadır.

Tablo 3. "LCM piyano sertifika sınavları için kullanılan kitapların İngilizce olmasına yönelik görüşleriniz nelerdir?” Sorusuna Verilen Yanıtların Dağılımı

\begin{tabular}{lccll}
\hline Kategoriler & $\mathrm{f}$ & $\%$ & İfade Örnekleri \\
\hline $\begin{array}{l}\text { Kitapları anlamakta güçlük } \\
\text { çekilmesi }\end{array}$ & 17 & 73.9 & $\begin{array}{l}\text { Benim İngilizcem iyi değil, bilen birilerine } \\
\text { sürekli çeviri yaptırmak zorunda kalıyorum. }\end{array}$ \\
\hline $\begin{array}{l}\text { Kitapları anlamakta sorun } \\
\text { yaşanmaması }\end{array}$ & 6 & 26.1 & $\begin{array}{l}\text { Dil konusunda sıkıntım yok. Çeviri } \\
\text { yapabiliyorum. }\end{array}$ \\
\hline & Toplam & 23 & 100 & \\
\hline
\end{tabular}

Tablo 3 'te verilen dağ 1 lıma göre kitapları anlamakta güçlük çekilmesine ilişkin görüşlerin fazla olduğu $(\mathrm{f}=17)$, kitapları anlamakta sorun yaşanmamasına ilişkin görüşlerin ise az olduğu $(\mathrm{f}=6)$ belirtilmektedir.

Eğitimcilerin ifadeleri incelendiğinde; yabancı dil yönünden yetersiz olan eğitimcilerin kitapları anlamada sıkıntı yaşadıkları ve bu sıkıntıyı aşmak için çeşitli çözüm yolları aradıkları görülmektedir. Bu kategoriyle ilgili bir başka görüş şu şekildedir: "İngilizcem iyi olmadığı için açıklamalarda çok sıkıntı yaşıorum. Çeviri yaptırmak zorunda kalıyorum". Yabancı dil yönünden sıkıntısı olmayan eğitimcilerin ifadeleri incelendiğinde ise; kitapları anlamak açısından sorun yaşamadıkları fakat yabancı dil yönünden yetersiz olan eğitimcilerin ciddi sıkıntılar yaşayabilecekleri konusunda hemfikir oldukları görülmektedir. Bu kategoride dikkati çeken bazı örnek cümleler şöyledir: "Ben İngilizcem olduğu için sıkıntı çekmiyorum ama İngilizcesi olmayan bir eğitimci için sıkıntı doğuracağını düşünüyorum".

"LCM piyano kitaplarında yer alan müzikal kazanımlar hakkındaki görüşleriniz nelerdir?" sorusuna ilişkin bulgular tablo 4'te yer almaktadır.

Tablo 4. "LCM piyano kitaplarında yer alan müzikal kazanımlar hakkındaki görüşleriniz nelerdir?" Sorusuna Verilen Yanıtların Dağılımı

\begin{tabular}{|c|c|c|c|}
\hline Kategoriler & $\mathrm{f}$ & $\%$ & İfade Örnekleri \\
\hline $\begin{array}{l}\text { Besteciler hakkında yeterli bilgi } \\
\text { olması }\end{array}$ & 5 & 12.2 & $\begin{array}{l}\text { Besteciler hakkında geniş bilgilere yer } \\
\text { verilmiş. }\end{array}$ \\
\hline $\begin{array}{l}\text { Besteciler hakkında yeterli bilgi } \\
\text { olmaması }\end{array}$ & 11 & 26.8 & Besteciler hakkında yüzeysel bilgi verilmiş. \\
\hline Eserler hakkında yeterli bilgi olması & 7 & 17.1 & $\begin{array}{l}\text { Eserler hakkında güzel ve ayrıntılı bilgi } \\
\text { verildiğini düşünüyorum. }\end{array}$ \\
\hline $\begin{array}{l}\text { Eserler hakkında yeterli bilgi } \\
\text { olmaması }\end{array}$ & 3 & 7.3 & $\begin{array}{l}\text { Kitaplarda beni tatmin edecek kadar eserler } \\
\text { hakkında bilgi verilmiyor. }\end{array}$ \\
\hline $\begin{array}{l}\text { Müzikal dinamikler (legato, staccato } \\
\text { vb.) hakkında yeterli bilgi verilmesi }\end{array}$ & 6 & 14.6 & $\begin{array}{lrrr}\text { Kitap } & \text { içerisinde } & \text { müzikal dinamikler ile } \\
\text { alakalı } & \text { yeterli } & \text { açıklama olduğunu } \\
\text { düşünüyorum. } & & \\
\end{array}$ \\
\hline $\begin{array}{l}\text { Müzikal dinamikler (legato, staccato } \\
\text { vb.) hakkında yeterli bilgi verilmemesi }\end{array}$ & 5 & 12.2 & $\begin{array}{l}\text { Eserler içerisinde müzikal terimlere ve } \\
\text { ifadelere yer verilmiş ama bunların } \\
\text { açılamalarına denk gelmedim. }\end{array}$ \\
\hline $\begin{array}{l}\text { Müzik terimlerinin evrensel müzik dili } \\
\text { yerine İngilizce ifade edilmesi }\end{array}$ & 4 & 9.8 & $\begin{array}{l}\text { Kitap içerisindeki çoğu hız teriminin İngilizce } \\
\text { verildiği dikkatimi çekti. }\end{array}$ \\
\hline Toplam & 41 & 100 & \\
\hline
\end{tabular}

Tablo 4'te LCM piyano kitaplarında besteciler hakkında yeterli bilgi olmamasına ilişkin görüşlerin en fazla olduğu $(\mathrm{f}=11)$, eserler hakkında yeterli bilginin olmamasına ilişkin görüşlerin ise en az olduğu $(\mathrm{f}=3)$ belirtilmektedir. 
Eğitimcilerin verdiği cevaplar incelendiğinde; LCM piyano kitapları içerisindeki performans bölümlerine ait eserlerin başlarında yer alan açılamalarda besteciler hakkında yeterli bilgiye yer verilmediği görülmektedir. Bu kategoride dikkati çeken bir başka örnek cümle şöyledir: "Bence besteciler hakkındaki bilgiler yeterli değil. Tanınmamış besteciler var, çok yüzeysel bilgi verilmiş".

Eğitimcilerin bu soruyu cevaplarken kitap içerisindeki bazı müzik terimlerinin evrensel müzik dili olan İtalyanca yerine İngilizce ifade edildiğine dikkat çektiği görülmektedir ( $f=4)$. Eğitimcilerin konuyla ilgili ifade ettikleri görüşleri şu şekildedir: "Kitap içerisindeki tüm bilgiler İngilizce, hız terimleri bile", "Kitaplarda nüans ve hız terimleri verilmiş ama hız terimlerinin çoğu İngilizce".

"LCM piyano kitaplarında yer alan teknik kazanımlar hakkındaki görüşleriniz nelerdir?" sorusuna ilişkin bulgular tablo 5'te yer almaktadır.

Tablo 5. "LCM piyano kitaplarında yer alan teknik kazanımlar hakkındaki görüşleriniz nelerdir?" Sorusuna Verilen Yanıtların Dağılımı

\begin{tabular}{|c|c|c|c|}
\hline Kategoriler & $\mathrm{f}$ & $\%$ & İfade Örnekleri \\
\hline $\begin{array}{l}\text { Artikülasyon işaretleri hakkında } \\
\text { yeterli bilgi verilmemesi }\end{array}$ & 1 & 2.6 & $\begin{array}{l}\text { Kitaplarda staccato çalman gerekiyor yazıyor } \\
\text { ama staccato çalış tekniği ile alakalı açıklama } \\
\text { yapılmamış. }\end{array}$ \\
\hline Teknik çalışmaların yeterli oluşu & 15 & 39.5 & $\begin{array}{l}\text { Gam ve arpej çalışmaları güzel sıralanmış. } \\
\text { Böyle çalışmalar yapmak öğrenciyi } \\
\text { geliştiriyor. }\end{array}$ \\
\hline Teknik çalışmaların yetersiz oluşu & 2 & 5.3 & $\begin{array}{l}\text { Kitaplar içerisindeki teknik çalışmaları yeterli } \\
\text { bulmuyorum. }\end{array}$ \\
\hline $\begin{array}{l}\text { Sınav için teknik çalışma } \\
\text { bölümündeki gam ve arpej } \\
\text { çalışmalarının seçimi }\end{array}$ & 4 & 10.5 & $\begin{array}{l}\text { Sınav için gam ve arpej çalışmalarını tercih } \\
\text { ediyorum. }\end{array}$ \\
\hline $\begin{array}{l}\text { Sınav için teknik çalışma } \\
\text { bölümündeki } \\
\text { study adlı çalışmaların seçimi }\end{array}$ & 16 & 42.1 & $\begin{array}{l}\text { Sınavda study adlı eserleri çaldırıyorum, gam } \\
\text { ve arpejleri tercih etmiyorum. }\end{array}$ \\
\hline Toplam & 38 & 100 & \\
\hline
\end{tabular}

Tablo 5'te yer alan yanıtların dağılımına göre sertifika sınavı için teknik çalışma bölümündeki study adlı çalışmaların seçimine ilişkin görüşlerin en fazla olduğu $(\mathrm{f}=16)$, artikülasyon işaretleri hakkında yeterli bilgi verilmemesine ilişkin görüşlerin ise en az olduğu $(\mathrm{f}=1)$ belirtilmektedir. Ayrıca eğitimcilerin kitapların içerisinde yer alan teknik çalışmaların yeterli olduğuna ilişkin görüşlerinin fazla olduğu $(\mathrm{f}=15)$, sınavlarının teknik çalışma bölümleri için gam ve arpej çalışmalarını tercih eden eğitimcilerin sayısının ise az olduğu $(\mathrm{f}=4)$ görülmektedir.

Eğitimcilerin ifadeleri incelendiğinde; LCM piyano kitaplarında yer alan teknik çalışmaların yeterli olduğu ve öğrencilerin çalgı çalım tekniklerinin geliştirilmesi açısından fayda sağladığı görülmektedir. Başka bir eğitimcinin konuyla ilgili görüşü şöyledir: "Bu bölümü beğeniyorum. Öğrencileri geliştiriyor. Bizlere de Hanon'un teknik egzersiz kitabı dışında bir kaynak sağlamış oluyor". Ayrıca eğitimcilerin LCM sertifika sınavları için teknik çalışmalar bölümündeki gam ve arpej çalışmaları yerine study adlı eserlerin tercih edilmesi konusuyla ilgili ifade ettikleri görüşleri şu şekildedir: "Çok fazla gam ve arpej çalışması var. Sadece onları çalışarak bile ders bitebilir. Bu yüzden sınav için study adlı eserleri tercih ediyorum".

"LCM piyano kitaplarında yer alan teorik kazanımlar hakkındaki görüşleriniz nelerdir?" sorusuna ilişkin bulgular tablo 6'da yer almaktadır. 
Tablo 6. "LCM piyano kitaplarında yer alan teorik kazanımlar hakkındaki görüşleriniz nelerdir?" Sorusuna Verilen Yanıtların Dağılımı

\begin{tabular}{lccl}
\hline \multicolumn{1}{c}{ Kategoriler } & $\mathrm{f}$ & $\%$ & \multicolumn{1}{c}{ İfade Örnekleri } \\
\hline Yeterli teorik açıklamanın bulunması & 3 & 8.1 & $\begin{array}{l}\text { Kitapların işitme bölümlerinde yeterli teorik } \\
\text { açıklamanın yer aldığını düşünüyorum. }\end{array}$ \\
\hline $\begin{array}{l}\text { Yeterli teorik açıklamanın } \\
\text { bulunmaması }\end{array}$ & 16 & 43.2 & $\begin{array}{l}\text { Kitapları içerisindeki konuların teorik } \\
\text { açılamalarını olduğu bir bölüm } \\
\text { görmedim. }\end{array}$ \\
\hline $\begin{array}{l}\text { Özengen müzik eğitimi amaçlı çalg1 } \\
\text { eğitimi alan bireyler için zor olması }\end{array}$ & 14 & 37.8 & $\begin{array}{l}\text { Hobi eğitimi alan bir birey için bu kadar } \\
\text { yüklü teorik bilgiye gerek olmadığını } \\
\text { düşünüyorum. }\end{array}$ \\
\hline $\begin{array}{l}\text { Özengen müzik eğitimi amaçlı çalg1 } \\
\text { eğitimi alan bireyler için uygun olması }\end{array}$ & 4 & 10.8 & $\begin{array}{l}\text { Bizim ülkemiz için zor olabilir ama evrensel } \\
\text { boyutlarda baktığımızda uygun olduğunu } \\
\text { düşünüyorum. }\end{array}$ \\
\hline Toplam & 37 & 100 & \\
\hline
\end{tabular}

Tablo 6'da yer alan "LCM piyano kitaplarında yer alan teorik kazanımlar hakkındaki görüşleriniz nelerdir?" sorusuna ilişkin eğitimcilerin verdiği yanıtların dağılımına göre kitaplar içerisinde yeterli teorik açıklamanın bulunmamasına ilişkin görüşlerin en fazla olduğu $(f=16)$, yeterli teorik açıklamanın bulunmasına ilişkin görüşlerin ise en az olduğu $(\mathrm{f}=3)$ görülmektedir.

Eğitimcilerin kitaplar içerisinde yeterli teorik açıklamanın bulunmadığ 1 ve kitapların özengen müzik eğitimi amaçlı çalg1 eğitimi alan bireyler için zor olduğu ile ilgili görüşleri şu şekildedir: "Kitaplarda birçok müzik teriminin açıklaması yok. Benim de bilmediklerim çıkıyor ve araştırıp öğrenmek zorunda kalıyorum", "Kitap içerisinde geçen müzikal işaretlerin teorik açıklamalarının olduğu bir bölüm yok".

“Özengen piyano eğitimi alan bir öğrencinin LCM sertifika sınavı odaklı çalışmalar yapması, çalgısına yönelik yaptığı çalışmaları sizce nasıl etkilemektedir?” sorusuna ilişkin bulgular tablo 7'de yer almaktadır.

Tablo 7. "Özengen piyano eğitimi alan bir öğrencinin LCM sertifika sınavı odaklı çalışmalar yapması, çalgısına yönelik yaptığı çalışmaları sizce nasıl etkilemektedir?" Sorusuna Verilen Yanıtların Dağılımı

\begin{tabular}{|c|c|c|c|}
\hline Kategoriler & $\mathrm{f}$ & $\%$ & İfade Örnekleri \\
\hline $\begin{array}{l}\text { Çalgı başarısına olumlu } \\
\text { etkisi }\end{array}$ & 6 & 28.6 & $\begin{array}{l}\text { Çalgıya karşı daha motive ederek öğrenciyi } \\
\text { geliştirdiğini düșünüyorum. }\end{array}$ \\
\hline $\begin{array}{l}\text { Çalgı başarısına olumsuz } \\
\text { etkisi }\end{array}$ & 15 & 71.4 & $\begin{array}{l}\text { Sınav kaygısı nedeniyle öğrencilerimin çalg1 } \\
\text { çalışmaktan soğuduğunu düşünüyorum. }\end{array}$ \\
\hline Toplam & 21 & 100 & \\
\hline
\end{tabular}

Tablo 7'de yer alan yanıtların dağılımına göre LCM uluslararası sertifika programlarının çalgı başarısına olumsuz etkisinin olduğuna ilişkin görüşlerin fazla olduğu ( $\mathrm{f}=15)$, LCM uluslararası sertifika programlarının çalgı başarısına olumlu etkisinin olduğuna ilişkin görüşlerin ise daha az olduğu $(\mathrm{f}=6)$ dikkati çekmektedir.

Eğitimcilerin ifadeleri incelendiğinde; LCM sertifika sınavlarına yönelik çalışmalar yapmanın, özengen piyano eğitimi alan öğrencilerin sınav kaygısı yaşamasına neden olmasından dolayı çalgı başarısını olumsuz yönde etkilediği görülmektedir. Bu kategori ile ilgili başka bir örnek ifade şu şekildedir: "Sınav kaygısı yüzünden normalde çok başarılı olan öğrencim çalışmamaya başladı ve sınava girmek istemediğini söyledi".

Eğitimciler tarafından LCM sertifika sınavlarına yönelik çalışmalar yapmanın, özengen piyano eğitimi alan öğrencilerin çalgı başarısına olumlu etkisi olduğu fakat çalışma disiplinine bağlı olarak başarının değişkenlik gösterebileceği belirtilmektedir. Eğitimcilerin bu kategori ile ilgili görüşleri şu şekildedir: "Sınavlara hazırlanan öğrenciler daha disiplinli oluyorlar", 
“Öğrenciden öğrenciye farkl1lık gösterdiğini düşünüyorum. Disiplinli öğrenciler için sınav odaklı çalışmak motive edici olabiliyor".

"LCM piyano kitaplarından, sertifika programına dâhil etmediğiniz öğrencileriniz için faydalanıyor musunuz?" sorusuna ilişkin bulgular tablo 8'de yer almaktadır.

Tablo 8. "LCM piyano kitaplarından, sertifika programına dâhil etmediğiniz öğrencileriniz için faydalanıyor musunuz?” Sorusuna Verilen Yanıtların Dağılımı

\begin{tabular}{cccc}
\hline Kategoriler & f & $\%$ & İfade Örnekleri \\
\hline $\begin{array}{c}\text { Kitaplardan sertifika programı dışında } \\
\text { faydalanılması }\end{array}$ & 20 & 100 & $\begin{array}{l}\text { Kaynak çeşitliliği açısından derslerimde } \\
\text { bu kitaplardan yararlanıyorum }\end{array}$ \\
\hline Toplam & 20 & 100 & \\
\hline
\end{tabular}

Tablo 8'de yer alan "LCM piyano kitaplarından sertifika programına dâhil etmediğiniz öğrencileriniz için faydalanıyor musunuz?” sorusuna ilişkin eğitimcilerin tamamı kitaplardan faydalanıldığına ilişkin görüş belirtilmektedir ( $\mathrm{f}=20)$.

Eğitimcilerin ifadeleri incelendiğinde; LCM piyano kitaplarının sertifika programı dışında yapılan çalışmalar için kaynak oluşturduğu, eğitimcilerin kitapların teknik çalışma ve performans bölümlerinden faydalandıkları görülmektedir. Eğitimcilerin konuyla ilgili ifade ettikleri görüşleri şu şekildedir: "Teknik egzersizler için bu kitapları kullanmayı tercih ediyorum", "Kaynak çeşitliliği açısından derslerimde bu kitaplardan yararlanıyorum".

“Eklemek istediğiniz başka bir görüşünüz var mı?" sorusuna ilişkin bulgular tablo 9'da yer almaktadır.

Tablo 9. "Eklemek istediğiniz başka bir görüşünüz var mı?” Sorusuna Verilen Yanıtların Dağlımı

\begin{tabular}{lccl}
\hline \multicolumn{1}{c}{ Kategoriler } & $\mathrm{f}$ & $\%$ & \multicolumn{1}{c}{ İfade Örnekleri } \\
\hline $\begin{array}{l}\text { LCM sertifika programları hakkında } \\
\text { bilgi eksikliği }\end{array}$ & 6 & 18.8 & $\begin{array}{l}\text { Bu programların öğrenciye ne yararlar } \\
\text { sağlayacağını bilmiyorum }\end{array}$ \\
\hline $\begin{array}{l}\text { MEB sertifikalarının geçerliliğinin } \\
\text { olmadığı düşüncesi }\end{array}$ & 13 & 40.6 & $\begin{array}{l}\text { MEB sertifikasının geçerliliğinin olmasını } \\
\text { isterdim }\end{array}$ \\
\hline $\begin{array}{l}\text { Sertifika sınavları hazırlık sürecinde } \\
\text { kitap kullanımı için öğretmen ihtiyacı }\end{array}$ & 13 & 40.6 & $\begin{array}{l}\text { Öğretmenin kitap içerisinde geçen bütün } \\
\text { terim ve ifadeleri öğrencisine göstermesi } \\
\text { isteniyor }\end{array}$ \\
\hline Toplam & 32 & 100 & \\
\hline
\end{tabular}

Tablo 9'da yer alan "Eklemek istediğiniz başka bir görüşünüz var mı?” sorusuna ilişkin eğitimcilerin verdiği yanıtların dağılımına göre MEB sertifikalarının geçerliliğinin olmadığı düşüncesi ( $\mathrm{f}=13$ ) ve sertifika sınavları hazırlık sürecinde kitap kullanımı için öğretmen ihtiyacına ilişkin görüşlerin ( $\mathrm{f}=13)$ fazla olduğu, bu iki kategorinin aynı frekans değerine sahip olduğu, LCM sertifika programları hakkında bilgi eksikliğinin olduğuna ilişkin görüşlerin ise az olduğu $(\mathrm{f}=6)$ belirtilmektedir.

\section{TARTIŞMA, SONUÇ VE ÖNERILER}

Uluslararası sertifikalı müzik eğitimi programlarından LCM piyano programının özengen müzik eğitimi veren piyano eğitimcilerinin görüşleri doğrultusunda incelenmesine ilişkin olarak gerçekleştirilen bu araştırma kapsamında elde edilen başlıca sonuçlar aşağıda yer almaktadır.

Ülkemizdeki uluslararası sertifika programlarının piyano eğitimcileri tarafından yeterince araştırılmadığı ve çevrelerindeki piyano eğitimcilerinden duydukları kadarıyla bilgi sahibi oldukları, piyano eğitimcilerinin Milli Eğitim Bakanlığına bağlı çeşitli kurslar kapsamında faaliyet gösteren sanat kursları tarafından verilen sertifikaların uluslararası denkliği olsaydı bu programları tercih etmeyecekleri, bu programları uluslararası geçerliliği olan bir sertifikaya sahip 
olabilmeleri için kullandıkları görülmektedir. Görüşülen piyano eğitimcilerinin büyük bir bölümünün ülkemizde hangi uluslararası sertifika programlarının faaliyet gösterdiği konusunda yeterli bilgiye de sahip olmadıkları görülmektedir. Araştırma dâhilinde incelenen LCM piyano program ve kitaplarının uluslararası sertifika programlarına öğrencilerini dâhil eden piyano eğitimcilerine faydalı olacağı düşünülmektedir.

Araştırmaya katılarak LCM programlarına öğrencilerini dâhil eden piyano eğitimcilerinin büyük bir bölümü tarafından bu programların öğrencilerin seviyesini geliştirmek ve belirli kazanımlara ulaşmalarını sağlamak için değil, öğrencilerin yurt dışına çıkarak eğitimlerine devam etme olasılığına fayda sağlaması amacıyla kullanıldığı görülmektedir. Bu durumun sanat kursları tarafindan uygulanan güncel programlarla beraber MEB sertifikalarına daha nitelik kazandırılması durumunda LCM programlarının çok daha az tercih edileceği düşünülmektedir.

LCM uluslararası sertifika programları, bu programların işleyişi ve verilen sertifikaların yurt dışı geçerliliği hakkında detaylı bilginin piyano eğitimcilerine verilmediği, piyano eğitimcilerinin sadece öğrenci hazırladıkları seviyenin kitaplarını inceledikleri, LCM uluslararası sertifika programına ait piyano kitaplarını genel olarak incelemedikleri görülmektedir.

Araştırmanın bir başka sonucuna göre LCM uluslararası sertifika programına ait piyano kitaplarının Türkçe açıklamalarının ve Türkçe sınav kılavuzlarının gerekli olduğu, piyano kitapları içerisinde yer alan müzikal, teknik ve teorik terimler ile ilgili açıklamaların yeterli olmadığı görülmektedir. Yabancı dil yönünden sıkıntı yaşayan piyano eğitimcileri, kitaplardaki açıklamaları anlayabilmek için çeviri yapmak veya yaptırmak zorunda kaldıklarını, bu durumun onlara zaman kaybettirdiğini ifade etmektedirler. Bu durumun önüne geçilebilmesi amacıyla yetkili sınav merkezleri tarafından LCM uluslararası sertifika sinavlarına ait kitapların detaylı Türkçe açıklamalarının olduğu dokümanların hazırlanarak bu programlara öğrencilerini dâhil eden piyano eğitimcilerine dağıtılması gerektiği düşünülmektedir. Bunun yanı sıra LCM sertifika sınavlarına katılacak aday öğrencilerin kitaplardaki kazanımlar ile ilgili istenilen yeterliliklere daha çabuk ulaşabilmeleri açısından farklı metotlarla desteklenmelerinin yarar sağlayacağı düşünülmektedir.

Araştırma kapsamında görüşme yapılan piyano eğitimcilerinin LCM uluslararası sertifika sınavlarına öğrenci hazırladıkları seviyeye ait kitaplar konusunda bilgi sahibi oldukları, diğer seviyelere ait kitapları incelemeyerek hedeflenen kazanımlar konusunda bilgi sahibi olmadıkları görülmektedir. Piyano eğitimcilerinin LCM piyano kitaplarını genel olarak incelemeleri sonucunda uluslararası sertifika programların amacının ve hedeflediği kazanımların daha iyi anlaş1lacağı düşünülmektedir.

Çalg1 eğitiminde izlenecek yolun kişiden kişiye farkl1lıklar göstermesi nedeniyle, her bireye belirlenen sabit plan ve programın uygulanmasının oldukça zor bir durum olduğu düşünülmektedir. Çalgı eğitiminde usta-çırak ilişkisi büyük önem taşımaktadır. Birçok piyano eğitimcisinin çalg1 eğitiminde belirli programları takip etmek yerine, kendi öğrencilik zamanlarında çalıştığı ve bildiği eser, etüt ve teknik çalışmaları kullanarak eğitim verdiği görülmektedir. Günümüzde mesleki müzik eğitiminde kullanılan gelenekselleşmiş eser, etüt ve teknik çalışmaların özengen müzik eğitimi açısından duyulan gereksinime tam olarak yanıt vermediği görülmektedir. Bu nedenle her geçen gün özengen piyano eğitimine kaynak sağlaması amacıyla farklı düzeylere hitap eden birçok kitap piyasaya sürülmektedir. Eğitimin kalitesinin arttırılması açısından eğitimcilerin yeni eserler tanıması, araştırması ve güncel metotları takip ederek kendi repertuvarlarını geliştirmeleri gerekmektedir.

$\mathrm{Bu}$ araştırmanın LCM programlarıyla ilgili olarak uluslararası sertifika verilmesi ve öğrencilerin eğitimlerine yurtdışında devam etmeleri durumunda fayda sağlayacağına ilişkin sonuçları, Özerdem (2021) tarafindan gerçekleştirilmiş benzer bir araştırma sonucuyla da örtüşmektedir. Bu çalışmada ülkemizde uygulamaları olan sertifikalı müzik eğitimi programları tanıtılmış ve bu programlar arasında yer alan Londra Trinity Koleji (TCL) piyano programı, 12 piyano eğitimcisinin görüşleri doğrultusunda incelenmiş̧tir. Araştırma sonuçlarına göre, piyano 
eğitimcilerinin TCL piyano sertifika programını tercih etme nedenleri olarak en yüksek oranda (\%50) bu programın uluslararası sertifika vermesi gösterilmiştir. Piyano eğitimcileri, özellikle yurt dışında eğitimine devam etmek isteyen öğrencilere belli avantajlar sağlaması ve aldıkları eğitime dair belge verilmesini TCL müzik eğitimi programının tercih nedenleri arasında göstermiş̧lerdir.

Aynı çalışmada TCL piyano sertifika programının kitap ve sınav ücretlerinin döviz olarak hesaplanıp ödenmesiyle ilgili olumsuz yanlarından da söz edilmiştir. Görüşleri alınan piyano eğitimcileri, maddi yetersizlikleri olan çok sayıda yetenekli öğrencinin sertifika sınavlarına katılamadığını belirtmişlerdir (Özerdem, 2021). Bu durum, London College of Music uluslararası sertifikalı piyano programı ile ilgili mevcut araştırmanın program ücretleriyle ilgili sonuçlarıyla benzerlik göstermektedir. Araştırma sonuçları incelendiğinde piyano eğitimcileri tarafından LCM program ücretlerinin yüksek olduğuna ilişkin görüşlerinin belirtildiği görülmektedir. LCM eğitim programları, yapılan sınavlar sonucunda verilen sertifikaların uluslararası geçerliliği nedeniyle özengen piyano eğitimi alan birçok öğrenci, veli ve piyano eğitimcisinin ilgisini çekmektedir. Ancak sertifika sınavlarının ve bu sınavlarda kullanılacak kitapların ücretleri döviz bazında hesaplanmaktadır. Bu durum uluslararası sertifika sınavlarında başarılı olabilecek birçok yetenekli öğrenciyi ve ailesini olumsuz etkilemektedir. Program maliyetlerinin aileleri ekonomik açıdan kaygıya düşürmesinin piyano eğitimcilerinin uluslararası sertifika programlarına öğrenci yönlendirmeleri açısından olumsuz etkileri olduğu düşünülmektedir.

$\mathrm{Bu}$ araştırma London College of Music uluslararası sertifikalı piyano programı ile sınırlı tutulmuştur.Müzik eğitimcilerine LCM bünyesindeki diğer sertifika programlan ile ilgili benzer akademik çalışmalar yapılması önerilebilir. Yapılacak yeni araştırmaların özengen müzik eğitiminde yaygın olarak kullanılan uluslararası sertifika programlarının işlevinin anlaşılması açısından önem taşıyacağı düşünülmektedir. Ayrıca müzik eğitimcileri için, bilgi eksikliklerinin giderilmesi açısından ülkemizde kullanılan diğer uluslararası sertifika programlarının inceleneceği benzer araştırmaların yapılması önerilebilir.

\section{KAYNAKÇA}

Basut, F. (2013). Türkiye'de uygulanan kraliyet müzik okulu sınavlarının etki ve sonuçlarına yönelik bir değerlendirme. (Yayınlanmamıș Yüksek Lisans Tezi). Trakya Üniversitesi Sosyal Bilimler Enstitüsü. Edirne.

Büyüköztürk, Ş., Kılıç Çakmak, E., Akgün, Ö. E., Karadeniz, Ş. ve Demirel, F. (2014). Bilimsel araştırma yöntemleri. Ankara: Pegem Akademi Yayınları.

Cemalcılar, A. (1985). Illetişim sanatı olarak müziğin öğretim ve eğitim ortamlarındaki kurumsal yapısı ve yaygın eğitimde bir model önerisi. (Yayınlanmamış Doktora Tezi). Anadolu Üniversitesi Sosyal Bilimler Enstitüsü. Eskişehir.

Dumlavwalla, D. T. (2011). Approaching the examiner's chair: Chronicling the experiences of piano examiner apprentices for the royal conservatory of music. (Unpublished Doctoral Thesis). University of Toronto. Toronto. Erişim adresi: https://central.baclac.gc.ca/.item?id=TC-OTU-30055\&op=pdf\&app=Library\&oclc_number=1032908172

Hellman, D., \& Mcdowell, C. (2011). Backgrounds, teaching responsibilities and motivations of music education candidates enrolled in alternative certification music education programs. Research and Issues in Music Education, 9(1), 1-11. Erişim adresi: https://eric.ed.gov/?id=EJ960088

Karan, M. (2011). Özengen müzik eğitimi veren kurumlarda çalgı eğitimi alan öğrencilerin mesleki yönelimlerinin incelenmesi. (Yayınlanmamış Yüksek Lisans Tezi). Gazi Üniversitesi Eğitim Bilimleri Enstitüsü. Ankara. 
LCM. Program hakkında. Erişim adresi (14 Kasım 2021): https://www.uwl.ac.uk/academicschools/music/about-school

LCM. Sinavlar. Erişim adresi (14 Kasım 2021): https://lcme.uwl.ac.uk/exams/grades

Oktay, C. (2017). Türkiye'de özengen müzik eğitiminde uluslararası sertifikalı müzik eğitimi programlarının işlevinin incelenmesi. (Yayınlanmamış Yüksek Lisans Tezi). Marmara Üniversitesi Eğitim Bilimleri Enstitüsü. İstanbul.

Özerdem, D. M. (2021). Londra Trinity Koleji sertifikalı müzik eğitimi programı piyano dalının özengen müzik eğitimi açısından incelenmesi. (Yayınlanmamış Yüksek Lisans Tezi). Mehmet Akif Ersoy Üniversitesi Eğitim Bilimleri Enstitüsü. Burdur.

Rauscher, H. F, Shaw, G. L., \& Katherine N. K. (1995). (1995). Listening to Mozart enhances spatial-temporal reasoning: Towards a neurophysiological basis. Neuroscience Letters, 185, 44-47. Doi: 10.1016/0304-3940(94)11221-4

Saraç, S. ve Saraç, M. (2018). Piyano eğitimi ve kısa tarihi. Ankara: Müzik Eğitimi Yayınları.

Tarman, S. (2006). Müzik eğitiminin temelleri. Ankara: Müzik Eğitimi Yayınları.

Türkmen, E., F. (2017). Müzik eğitiminde öğretim yöntemleri. Ankara: Pegem Akademi.

Türkmen, U. (2010). Çocuğun bireysel toplumsal ve kültürel gelişiminde amatör müzik eğitiminin yeri problemleri ve çözüm önerileri. İlkögrretim Online Dergisi, 9(3), 960-970. Erişim adresi: https://dergipark.org.tr/en/download/article-file/90727

Uçan, A. (2005). Müzik Eğitimi, temel kavramlar-ilkeler-yaklaşımlar ve Türkiye'deki durum (3. Bask1). Ankara: Evrensel Müzikevi.

Yıldırım, A. ve Şimşek, H. (2016). Sosyal bilimlerde nitel araştırma yöntemleri. Ankara: Seçkin Yayıncilik.

\section{EXTENDED ABSTRACT}

\section{Introduction}

Music education, one of the most important field of art education, is a field that supports the individual's expressive skills, develops the aesthetic point of view and self-confidence, increases attention and comprehension skills, and enables them to discover their creative aspects.

Nowadays, interest in instrument education, which is one of music education dimensions, is increasing due to the gains it provides for the individual. Considering the interests and wishes of individuals, instrument education is usually given in private music education schools or private lessons.

In our coutry, internationally certified music education programs are applied by private institutions authorized as examination centers or by music educators who provide music education for amateurs. Demand for international certification programs is increasing day by day since the international validity of the documents provided in case of success of the examinations given to the individuals included in these programs. One of the internationally certified music education program in our country is the London College of Music (LCM) program.

This research, which describes the current situation of LCM program, for piano lessons in the amateur music education, is done to examine this program and the piano books in accordance with the opinions of piano educators who are proficient in music education. 


\section{Methods}

In this study, the interview technique, which is one of the qualitative research data collection methods, was used. The study group of the research consists of 20 piano educators who use the piano books of the LCM internationally certified music education program by including their students in the LCM international certificate program in Izmir. The data of the study were collected through semi-structured interviews. Content analysis was performed on data as a result of interviews with piano educators. In order to establish the internal validity of the study the data were analyzed by all of the two researchers.

\section{Discussion, Results and Recommendations}

The main results obtained within the scope of this research, which was carried out regarding the examination of the LCM piano program in accordance with the opinions of piano educators who are proficient in music education, are as follows.

It is established that there are many opinions that piano educators have difficulty in understanding the books ( $\mathrm{f}=17$ ). It is stated that the views on the lack of sufficient information about the composers in the LCM piano books were the highest $(\mathrm{f}=11)$, and the views on the lack of sufficient information about the works were the least $(\mathrm{f}=3)$. According to the results, it is determined that there are piano educators $(\mathrm{f}=16)$ who prefer the "study" in the technical study section for the certification exam. 16 piano educators expressed that about the lack of sufficient theorical explanations in the books.

According to the findings obtained here; it is observed that the educators who participated in the interview did not have sufficient information about the validity of the LCM international certificate program and certificates. It is also stated that this program is preferred due to the international validity of LCM certificates, but not every student who can be successful cannot be directed to these programs because of the high examination fees. However, it is stated that LCM piano books are used not only for the students who are included in the certificate programs but also they are used for the students who are not included in the programs.

When the results of the research are examined, it is seen that the explanations about the musical, technical and theoretical terms in the piano books are not sufficient. In addition, it is stated that the piano educators have a difficulty in understanding the books. So, it could be said that Turkish exam guide is necessary. 